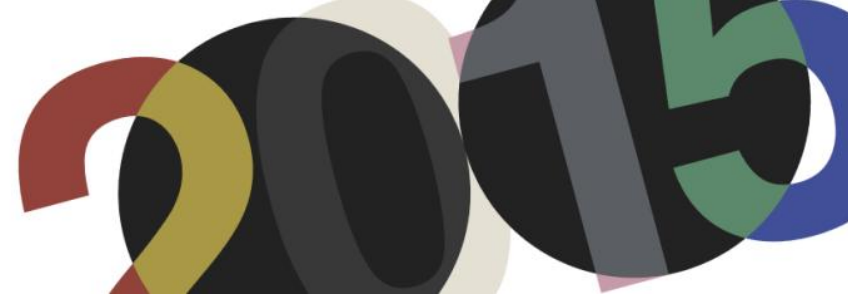

DOI: http://dx.doi.org/10.4995/LC2015.2015.814

\title{
La Ligne Claire de Le Corbusier. Time, Space, and Sequential Narratives
}

\author{
L.M. Lus Arana \\ Profesor Ayudante Doctor. Área de Composición Arquitectónica. Escuela de Ingeniería y Arquitectura, \\ Universidad de Zaragoza
}

\begin{abstract}
In 1921, issue 11-12 of L'Esprit Nouveau featured an article entitled "Toepffer, précurseur du cinema" where Le Corbusier, signing as 'De Fayet', vindicated the figure of Rodolphe Töpffer (1799-1846), a Swiss a pioneer of comics, as a key element in the development of cinema. Marginal as it may seem, this reference unveils a deeper relationship between Jeanneret and Töpffer's work which started in his childhood, and would have a key role in the development of some of Le Corbusier's trademark obsessions: travel, drawing, and cinematic narratives. In this context, "La Ligne Claire de Le Corbusier" proposes a close examination of the presence of graphic narrative and its aesthetics in Le Corbusier's early work in relation to its evolution from a sequential promenade architecturale to multispatial enjambment. The paper explores themes such as narrative and the inclusion of time in le Corbusier's Purist paintings, or his evolution from a painterly approach to drawing to an idealized, linear and synthetic rendering style.
\end{abstract}

Keywords: Sequence; Enjambment; Purism; Avant-Garde; Töpffer ; Bande Dessinée.

\section{Introduction: Le Corbusier, the Arts, and the Media}

In November 1921, issue 11-12 of L'Esprit Nouveau featured an article entitled "Toepffer, précurseur du cinema" . Signed by De Fayet, a penname shared by Amédée Ozenfant and Charles-Edouard Jeanneret, it vindicated the figure of Rodolphe Töpffer, and was accompanied by a selection of comic strips from Monsieur Pencil (created in 1831 and published in 1840), and Le Docteur Festus (1831/1846). Töpffer, born in Geneva in 1799, had been a Swiss schoolmaster, playwright, journalist, pedagogue, and painter who ran a boarding school for boys and was later was appointed Professor of Literature at the University of Geneva. A most prolific author, he published several children books, essays on art practice and theory, short and full-length novels, travel books focused on alpine excursions, and even an Essay on Physiognomy (Essai de physiognomonie, 1845). Literary success notwithstanding, Töpffer finally made his way into History books mostly due to his role as the Swiss father of comics ${ }^{2}$. Starting in the 1930s, Töpffer, who used to entertain his students with short stories and caricatures, began to produce a series of 'histoires en estampes' (literally 'stories in prints'). He produced his 'literature in pictures', which he printed through autography, a variation on lithography that allowed him to draw on specially prepared paper with a pen. This cheap and fast technique fostered the creation a lengthy series of

\footnotetext{
${ }^{1}$ I am indebted to Stanislaus von Moos, who pointed me towards his essay "Voyages en Zigzag" (In Rüegg, Arthur; Von Moos, Stanislaus (eds.): Le Corbusier before Le Corbusier: Applied Arts, Architecture, Painting, Photography, 1907-1922. New Haven: Yale University Press, 2002. pp. 22-43), where he outlined Le Corbusier's relationship with Töpffer. Many facts included here spring from his research on Le Corbusier's original documents in the Fondation Le Corbusier.

${ }^{2}$ For more information on Töpffer's life and work see: Kunzle, David: Father of the comic strip: Rodolphe Töpffer. Great Comics Artists Series. Jackson: University Press of Mississippi, 2007; and Groensteen, Thierry; Peeters, Benoît: Töpffer: L'invention de la Bande Dessinée. Paris: Hermann, 1994.
} 
works that encoded many of the parameters and mechanisms which would later define the medium, progressively becoming an immensely popular form all over Europe.

In fact, Töpffer's strips, as well as his other works, attracted the attention of fellow cartoonists and intellectuals alike, including both the illustrious scientist Auguste de la Rive and the romantics, such as Balzac, or Victor Hugo $^{3}$. They would even reach Johann Wolfgang von Goethe, who was particularly fond of them, and ultimately played a major part in Töpffer's decision to publish them ${ }^{4}$. Goethe was not the only major name of modern literature who appreciated some aspect of the Swiss teacher's oeuvre: Almost a century later, Leo Tolstoy cited La Bibliothèque de mon oncle [My Uncle's Library], one of Töpffer's most popular works in prose, as an early inspiration ${ }^{5}$. Outside the literary scene, Töpffer's influence can be tracked as far as Henri de Toulouse-Lautrec, whose sketchbook Cahier de Zigzags makes a direct reference to Voyages en Zigzag (1844), one of Töpffer's most popular books. He would not be the only one in his appreciation, since, as we will see, this book would have a crucial role in the shaping of Le Corbusier's obsessions during young Jeanneret's formative years ${ }^{6}$.
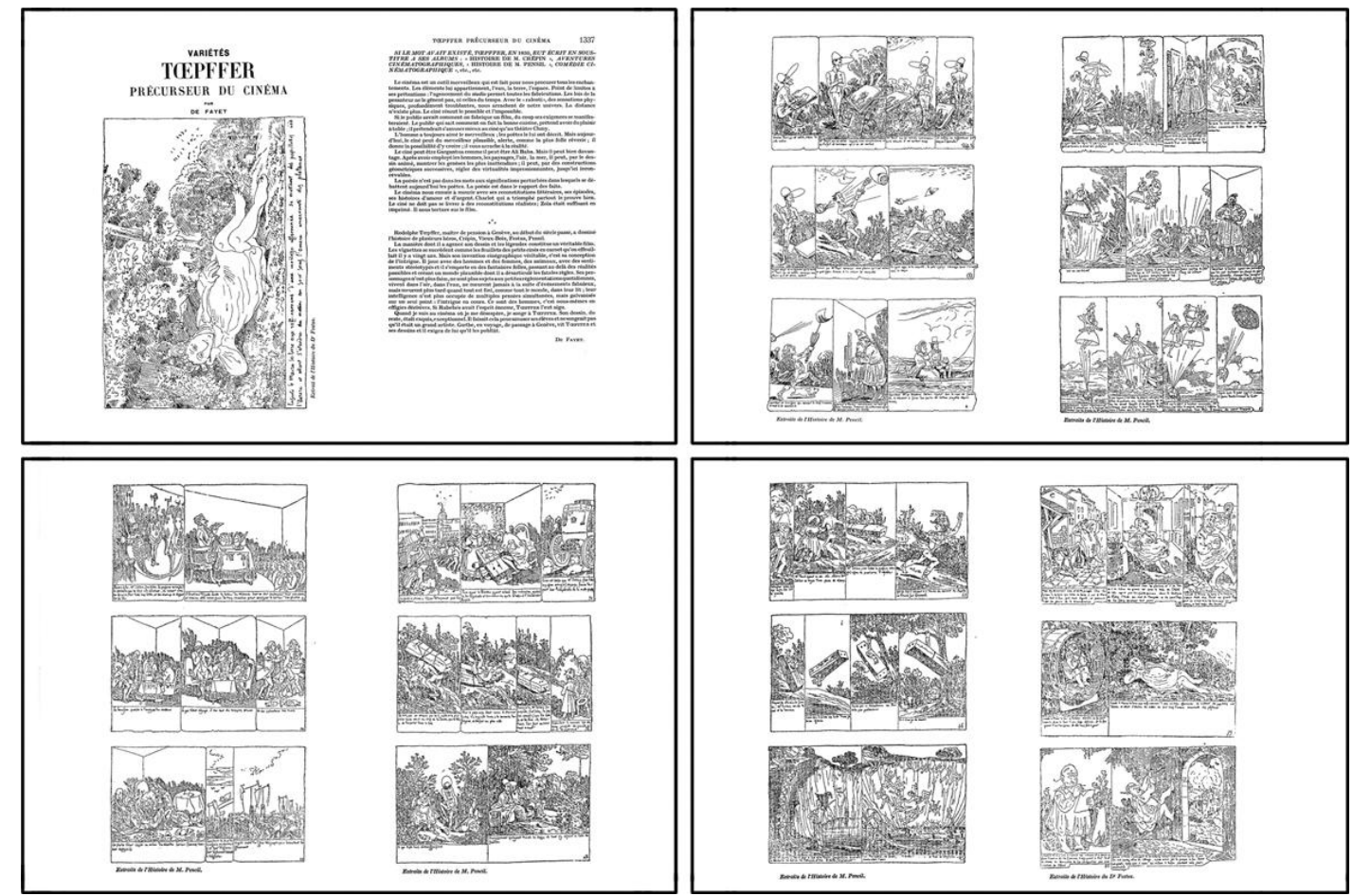

1. Le Corbusier on Töpffer: [1-4]. Le Corbusier: The eight plates of "Toepffer, précurseur du cinema”, in L'Esprit Nouveau 11-12, November 1921. OFLC-ADAGP

Of course, the publication of "Toepffer, précurseur.." can be explained by purely contextual reasons: In 1921, Töpffer's strips had been adapted into an animation film, Histoire de Monsieur Vieux-Bois (Lortac and Cavé, $1921)^{7}$, which prompted filmmaker Jean Choux to write three articles on the topic in the magazine La Suisse ${ }^{8}$.

\footnotetext{
${ }^{3}$ See Kunzle. Op. cit. p. 6.

${ }^{4}$ See cf. Von Goethe, Johan Wolfgang: Conversations of Goethe with Eckermann and Soret. London: George Bell \& Sons, 1874. An account of Goethe's impressions on Töepffer can be found in Kunzle. Op. cit.. pp. 49-56.

5 "Tolstoy confessed he was 'strongly influenced by... Töpffer (his Bibliothèque de Mon Oncle)' when he wrote Childhood, Boyhood, and Youth." Quoted in Aylmer, Maude: The Life of Tolstoy: First Fifty Years. New York: Dodd, Mead, 1910. pp. I, 160.

${ }^{6}$ See Kunzle. Op. cit. p. 151

${ }^{7}$ The film was a faithful adaptation of l'Histoire véritable des amours de Mr Vieux-Bois (title of the 1839 edition).
} 
Also, the publication of articles on items located somewhere in the periphery of official culture, be it architecture or Fine Arts, was not alien to the history of L'Esprit Nouveau, and, in fact, was very much in line with its very philosophy. The magazine where we can find pages devoted to architecture, painting, or poetry, also featured frequently images of machinery and vehicles, advertisements and digressions on the new cultural movements and the avant-garde, Apollinaire's calligrams, and even cartoons, be those drawn by Pablo Picasso, George Grosz, or by popular press cartoonists such as Léon Kern, Marcel Arnac, Barboni, Abel Faivre, Marcel Capy, or even Frans Masereel.

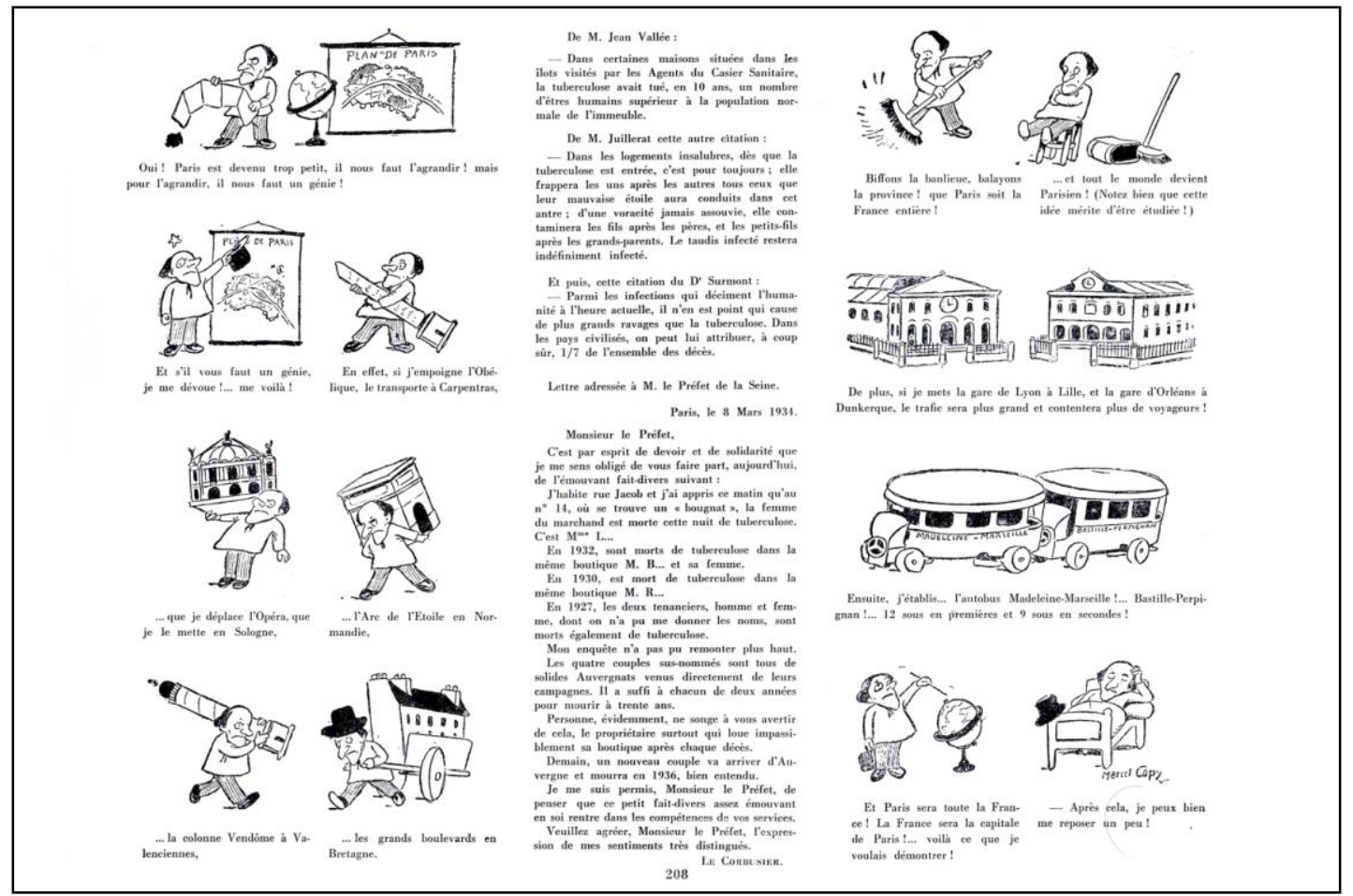

2. Des Cartoons, des Munitions: [5] Page 208 of Le Corbusier's La Ville Radieuse (1935) featuring the proto-comic "Paris trop petit", by Marcel Capy. (OFLC-ADAGP. Originally published in Le Journal No 12068 (Paris, November 1, 1925).

Le Corbusier frequently peppered his early manifestoes with cartoons clipped from contemporary newspapers, which fitted well his inflammatory prose, helping him underline his points. An assorted collection of cartoons, usually lifted from the Parisian conservative daily Le Journal, can be found in "Coupures de Journaux" (LEN $\mathrm{n}^{\circ}$ 25), and in its revised and expanded version published in Urbanisme (1924; 119-33), as well as in L'Almanach d'Architecture Moderne (1925), Une Maison, un Palais (1928), which reprinted some of the drawings from "Toepffer, précurseur..." , and even La Ville Radieuse (1935). Among those, the most outstanding case might be perhaps La Ville Radieuse, both because the cartoons are scattered throughout the book, interspersed in between the text, sketches, and plans, and because of the prominent presence of Marcel Capy, a prolific author and a favourite of Le Corbusier, who also included a note of gratitude to the cartoonist ("Merci, Capy!"; 120). Le Corbusier's relationship with caricature and cartoonists would grant him one of the infamous diplomas awarded by the architect-cartoonist by excellence, Saul Steinberg. The document, part of a series awarded to personalities

\footnotetext{
${ }^{8}$ The first of those articles was published on August 23, 1920. All three can be found in Edera, Bruno: Histoire du cinéma suisse d'animation. Lausanne: Cinémathèque suisse, 1978.

${ }^{9}$ Four panels from pages 23 and 24 of 'Histoire de Mr. Pencil' misquoted as 'Histoire de M. Pensil', by 'F. Töpper' (Genevois) appear in pages 188 and 189. See: Le Corbusier: Une maison - un palais. "A la recherche d'une unité architecturale.". Paris: Éditions Crès, "Collection de l'Esprit Nouveau", 1928.
} 
such as Igor Stravinsky, Charles Eames, Billy Wilder, Josef Albers, or Alberto Giacometti, amusingly entitled him to practice architecture, and was published in the fifth Volume of the Oeuvre Complète (1946-1952). In return, Le Corbusier would reportedly tell Steinberg: "You draw like a king".

All these diversions just underline Le Corbusier's polyhedral personality, along with the omnivore nature of his approach to design, which claimed for the need of a transversal understanding of the architectural fact. Le Corbusier's architecture was at its very core, part of a transdisciplinar exploration that had its origin in a fundamental interest in all the aspects of modernity, a complex, multi-faceted era that demanded a new spirit, a 'spirit of construction and synthesis ${ }^{\text {"10 }}$ that could gather all those parts together. Architecture became, in Le Corbusier's work, the discipline called upon to produce a true synthesis of the arts -including among those all forms of communication and technology. Along with this new understanding of the integration of the different disciplines, the modern era required the development of a new glance, a new eye capable of apprehending the rapid and multiple reality of the emerging urban world. It is in this context that we can frame Le Corbusier's interest in cinema, an urban medium whose mechanical eye, the eye of the camera, was capable of a glance that integrated time and space, thus becoming the perfect means to record and reproduce the experience of modern space epitomized by the modern city. As Georg Simmel put it, the city of the new century created in the observer a dramatic "intensification of nervous stimulation ${ }^{11 "}$. The modern flanêur, we should add, was one that became overwhelmed by an increasingly vertical space whose complexities could only be perceived through the lapse of time. This is the scenario where the pictorial avant-garde arose, where the multiple vision of collage and cubism bred, and where Le Corbusier's own experiments with Purism evolved in the 1920s. His interest on cinema, which resulted in fruitful relationships with artists such as Eisenstein -a man with an early fascination with cartoons as well- seems to explain sufficiently, in this sense Töpffer's presence in L'Esprit Nouveau. In fact, in his article, Le Corbusier based his argumentation on Töpffer's relevance in his alleged role as a forefather of cinema:

"Si le mot avait existé, Toepffer, en 1830, eut écrit en sous-titre à ses albums: "Histoire de Monsieur Crépin", aventures cinématographiques, "Histoire de M. Pensil"[sic], comédie cinématographique, etc., etc. [...] Rodolphe Toepffer, maître de pension à Genève, au début du siècle passé, a dessiné l'histoire de plusieurs héros (...) La manière dont il a agencé son dessin et les légendes constitue un véritable film. Les vignettes se succèdent comme les feuillets des petits cinés en carnet qu'on effeuillait il y a vingt ans. (...) Quand je suis à cinéma où je me désespère, je songe à TOEPFFER. Son dessin, du reste, était exquis, exceptionnel. Il faisait cela pour amuser ses élèves et ne songeait pas qu'il était un grand artiste."

These few references to Töpffer were scattered in a much longer reflection on cinema, which seemed to justify well enough the inclusion of the cartoonist. Once Le Corbusier's attraction towards the new medium of film has been established, it seems only logical that Töpffer's Muybridge-like sequential stories attracted his attention, even if out of sheer archaeological curiosity. However, his infatuation with the Swiss pedagogue was more than a circumstantial, or passing one: In a letter to August Klipstein from 1911, Le Corbusier asked him to "please send [him] the following book: the adventures of Monsieur Vieux-Bois", adding that in it, he would "find a French or Latin Busch, obviously a precursor as a draftsman", and concluding that he "should be delighted to

10 "Il y a un esprit nouveau cést un esprit de construction et de synthèse guidé par une conception claire." "L'Esprit Nouveau", in L'Esprit Nouveau $\mathrm{n}^{\circ} 1,1918$.

${ }^{11}$ See Simmel, Georg: "The Metropolis and Mental Life". Adapted by D. Weinstein from Kurt Wolff (Trans.): The Sociology of Georg Simmel. New York: Free Press, 1950. pp.409-424. 
write a doctoral thesis on Töpffer" ${ }^{12}$ With this last sentence, Le Corbusier also showed a more than casual knowledge of graphic narrative: The 'Busch' he mentions is Wilhelm Busch (1832 - 1908), a German cartoonist, painter and poet, famous because of his illustrated poems and for creating the characters Max und Moritz. Actually, Jeanneret's knowledge of Töpffer's work was older and deeper, and I would argue that it would evolve into a life-long relationship, in the sense that it seems to have helped shape some of Le Corbusier's later obsessions: From the fascination with travel, and an ascetic sense of design that paired his synthetic approach to drawing, to his penchant for the overlaps between narrative and architecture, and the introduction of time in the perception of architectural space.

\section{Photography and Drawing. Towards Le Corbusier's Ligne Claire.}

As Stanislaus von Moos explains in his eponymous Voyages in Zigzag, Le Corbusier's relationship with Töpffer dates back to his childhood, and to Voyages en zigzag, ou excursions d'un pensionnat en vacances dans les cantons suisses et sur le revers italien des Alpes. The book, written by Töpffer and published for the first time in Paris in 1844, was one of several volumes, targeted to a young audience, where the Swiss schoolmaster recounted, as the subtitle states, the "excursions of a boarding school on vacation In the Swiss cantons as well as on the Italian slopes of the Alps". Richly illustrated both by Töpffer and Alexandre Calame, who provided fifteen drawings of Alpine landscapes, the book offered "a Romantic celebration of the Alps, mixed with genre scenes" that made it a perfect reading for youngsters. As von Moos notes, "[t]he book's many charming illustrations of the Alps, its humor and edifying morals, had earned it a place of honor on bookshelves of many middle-class households in French-speaking Switzerland by $190{ }^{\text {",13 }}$ Young Charles-Edouard Jeanneret's family was one of those, and von Moos rightfully finds in Töpffer's "Petit Tour" through Switzerland the origin of Le Corbusier's passion for travelling, for creating carnets de voyage, and -I would add- of his infatuation with the figure of Töpffer, and the latter's influence on the development of yet another passion: drawing.

Through his brother Albert ${ }^{14}$, we know that young Charles-Edouard's earliest drawings were done as copies after the images of the Alps published in Voyages en Zigzag. In the light of this, and with the advantage of knowing the development of Le Corbusier's subsequent career, as well as his vindication of Töpffer's figure, it is not difficult to see shades of Töpffer's nervous line in the evolution of Le Corbusier's trademark linear style. As Beatriz Colomina explains in "Le Corbusier and Photography", his alleged despise of photography, sustained by statements such as "[t]he camera is a tool for idlers, who use a machine to do their seeing for them" or "[d]on't take photographs, draw; photography interferes with seeing, drawing etches into the mind", cannot

\footnotetext{
12 “A propos, faites venir ce livre-ci: les aventures de Monsieur Vieux-Bois (édité à Genève). Vous póuvrez voir là un Busch francais, latin, et surtout un précurseur comme dessinateur. Je ferias volontiers une these de doctorat sur Töpffer". CharlesEdouard Jeanneret to August Klipstein, n.d. (1911); FLC E 26-145. Quoted in Rüegg. Op. Cit., note 13, p. 283. Le Corbusier refers to Histoire de M. Vieux Bois (1827/ 1837), also known as Les amours de Mr. Vieux Bois or simply Monsieur Vieuxbois. In his "Catalogue de la bibliotheque Le Corbusier avant 1930" (Paris, February 1970), Paul V. Turner lists two books by Töpffer: Le Docteur Festus (Paris, s.d.) and Voyage à la Grande Chartreuse (Genève, 1920).

${ }^{13}$ All previous quotations: Rüegg. Op. Cit., p. 23

${ }^{14}$ From a personal communication by Albert Jeanneret. Le Lac, Corseaux, c1968. See VON MOOS (1968); 13. This reference does not appear in the English edition of the book.

${ }^{15}$ Corbusier, Le: Creation is a patient search. New York: Frederick Praeger, 1960, p. 37. Quoted in Colomina, Beatriz: Le Corbusier and Photography. In Assemblage. October 1987, № 4. p. 8.

${ }^{16}$ In Wogensky, André: Le Corbusier Sketchbooks. Cambridge: MIT Press and New York: Architectural History Foundation, 1981- 82. The quotation appears in Vogt, Adolf Max: "Remarks on the 'Reversed' Grand Tour of Le Corbusier and Auguste Klipstein”. In Assemblage. October 1987, № 4. p. 41
} 
be taken at face value: As a medium of the Temps Nouveaux, the mechanical eye of the camera forcefully had been reserved a prominent role in the recording of the emergent, mechanical, and a (newly?) objective reality. In fact, Le Corbusier made extensive use of photographs in his travels in the East, and photographic image played a fundamental part in the communication of the message of his first books, from Vers une architecture (1923) to L'Art Decoratif d'ajourd'hui (1925). However, it is also clear that while photography was an undeniably useful tool, drawing was a far superior one, because "[b]y working with our hands, by drawing," he wrote, "we enter the house of a stranger, we are enriched by the experience, we learn." 17 Thus, when reviewing the materials in Viaggio in Oriente, or the archives of L'Esprit Nouveau, we find many instances where Le Corbusier obsessively draws "after" photographs (both his own and those found in newspapers or catalogues, as well as postcards), as in an attempt to remove anything superfluous, and capture their essence. We know that Le Corbusier used to sketch his buildings repeatedly, and even when dealing with photographs, he could not resist to endlessly edit them, whiting out with an airbrush anything that obstructed the understanding of the idea(l) in them.
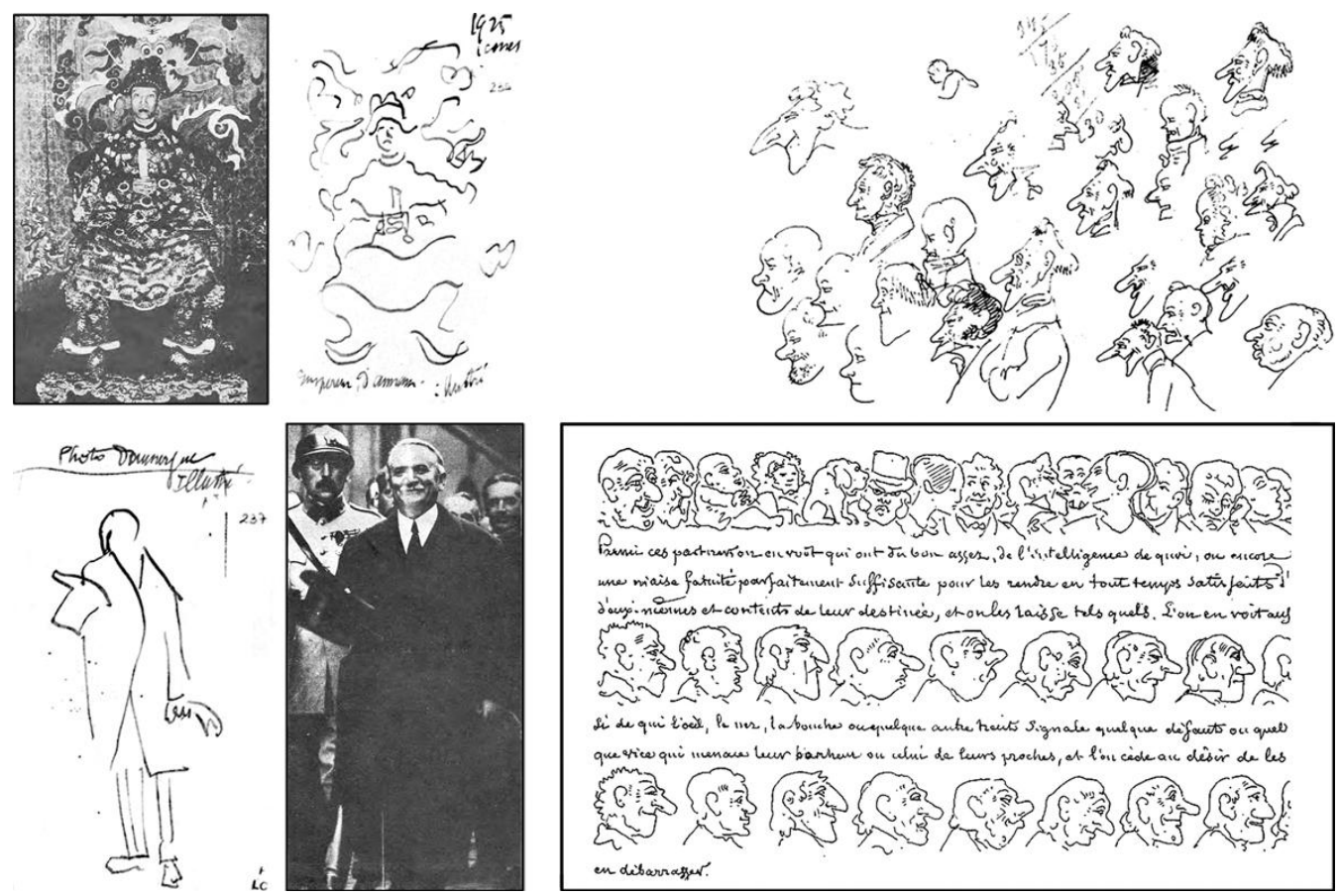

3. [6-9] Photographs from L'lllustre of Emperor Khai Dinh and President Gaston Doumerge and drawings done after them, as layouts for L'Art decoratif d'aujourd'hui, 1925. OFLC-ADAGP [10] Caricature studies by Rodolphe Töpffer, date unknown. [11] Excerpt from Töpffer's Essai de physiognomonie.

"Les perspectives qui accompagnent ses projets (...) sont exécutées au trait. Le dessin est épuré à l'extrême: seuls les contours (...) sont tracés. Si ces dessins appartenaient au genre de la bande dessinée, on les rapprocherait de l'école belge de la 'ligne claire'."18

Again, it is difficult not to think of Töpffer when picturing Le Corbusier obsessively reducing complex photographs into drawings made with a few lines -a process not unlike the method used by Hergé, who famously

\footnotetext{
${ }^{17}$ Corbusier, Le, Op. cit. Quoted in Colomina, Op. cit., p. 8.

${ }^{18}$ Migayrou, Frédéric; Cinqualbre, Olivier: Le Corbusier: Mesures de l'homme. Catalogue of the Exhibition. Paris: Editions du Centre Pompidou, 2015.
} 
traced his own sketches over and over, until only the lines that were 'the clearest and simplest' remained on the page. In this sense, illustrations that appeared in L'Esprit Nouveau, such as "Boudoir" (LEN no 27), or "Cabinet de Travail" ( $L E N \mathrm{n}^{\circ} 28$ ), both belonging to the Atelier Primavera des Magasins du Printemps, would not seem out of place in a comic book by masters of the Franco-Belgian 'ligne claire' such as Hergé, Joost Swarte or Yves Chaland. The overlaps with Töpffer are particularly vivid in Le Corbusier's sketches of human figures after photographs, where organic, curving lines instilled the figures with a dynamism and liveliness that the inevitably static photographs lacked. As opposed to the staleness of photography, or traditional architectural rendering, Le Corbusier's trademark ligne claire style allowed his architectural representations to convey a meaning, transmit a message, or even tell a story. Colomina pictures Le Corbusier 'reworking... his fetishized drawings'. However, it seems worth adding that there was a particular type of drawing that Le Corbusier had a fetish for: drawings that progressively left L'Eplatenier's naturalistic approach behind and searched for a certain iconic stylization that rendered his buildings, and reality itself, in their ideal state ${ }^{19}$-or perhaps it just rendered them as Le Corbusier saw them. If we design with the images we have in our mind, one wonders to what point Jeanneret's mind might had been shaped by Töpffer's calligraphic imagery, and whether to what point the latter's synthetic approach to drawing appeared as a perfect way to convey graphically the spirit of synthesis the former was looking for ${ }^{20}$. In the suspended reality of a kindly drawing style, standing somewhere between the architectural rendering and the sketch, Le Corbusier's machine-houses overcame their previous artificiality and blended with their surroundings. Töpffer's 'ligne claire' presented itself as a tool to represent the utopian dimension of modern architecture.

\footnotetext{
${ }^{19}$ Compare, for instance, the extensive use of (heavily edited) architectural and vehicle photographs in "Trois rappels a messieurs les architectes" (LEN n ${ }^{\circ}$ 1), or "Des yeux qui ne voient pas... Les Paquebots" (LEN nº 8) with the ubiquity of handmade drawings in the articles of later issues, such as "Maisons en Série" (LEN n $\left.{ }^{\circ} 13\right)$.

${ }^{20}$ Obviously, this 'ligne claire' style is not alien to the tradition of architectural representation. Even in the same period we can find examples which bear even a closer resemblance to Hergé's Tintin. Victor Bourgeois's renderings for La Cité Moderne in Berchem-Sainte-Agathe from 1922-25 are very explicit in this sense. What makes Le Corbusier's case especially relevant is his refusal to give an accurate definition of the architectural object, which rather stays in an intermediate stage of evanescence, constructed by imprecise lines and dots. Le Corbusier's drawings seem to want to retain the narrative options of the cartoon, turning the buildings into characters which, subject to multiple readings by the viewer, evolve and interweave with their environments, blending with them.
} 

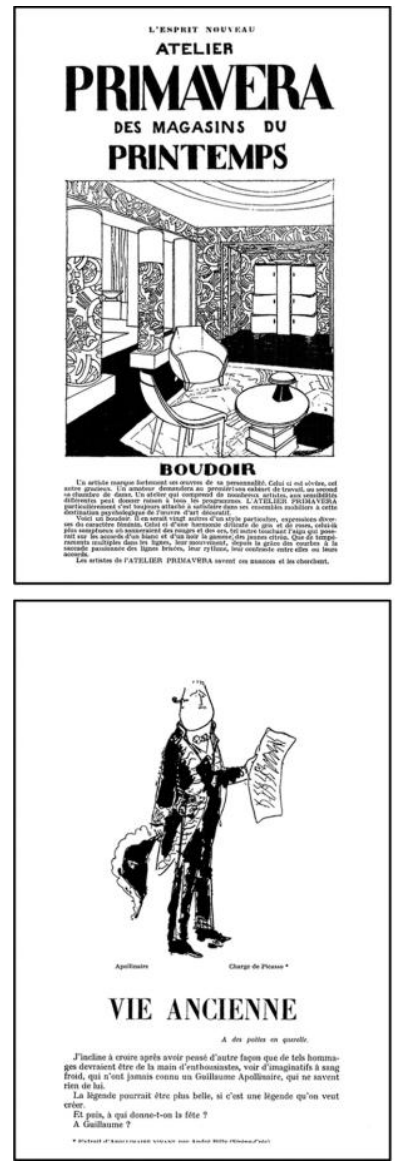
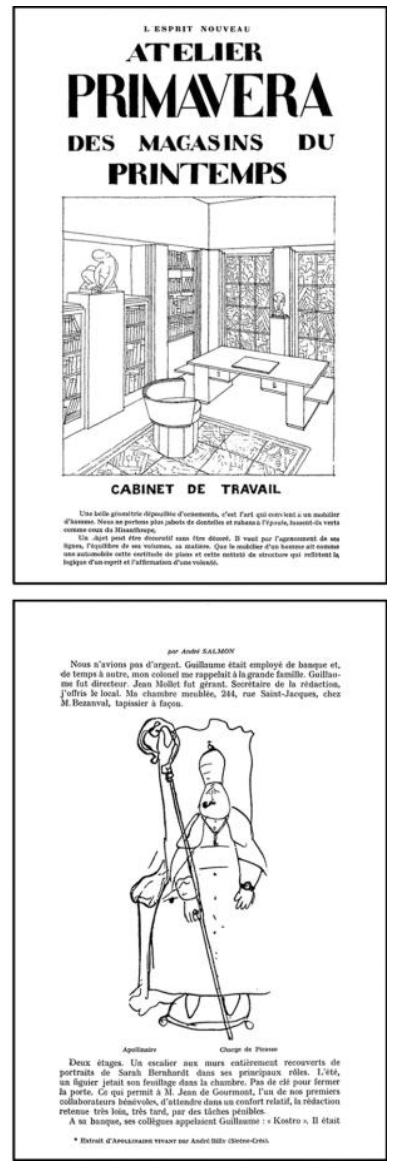
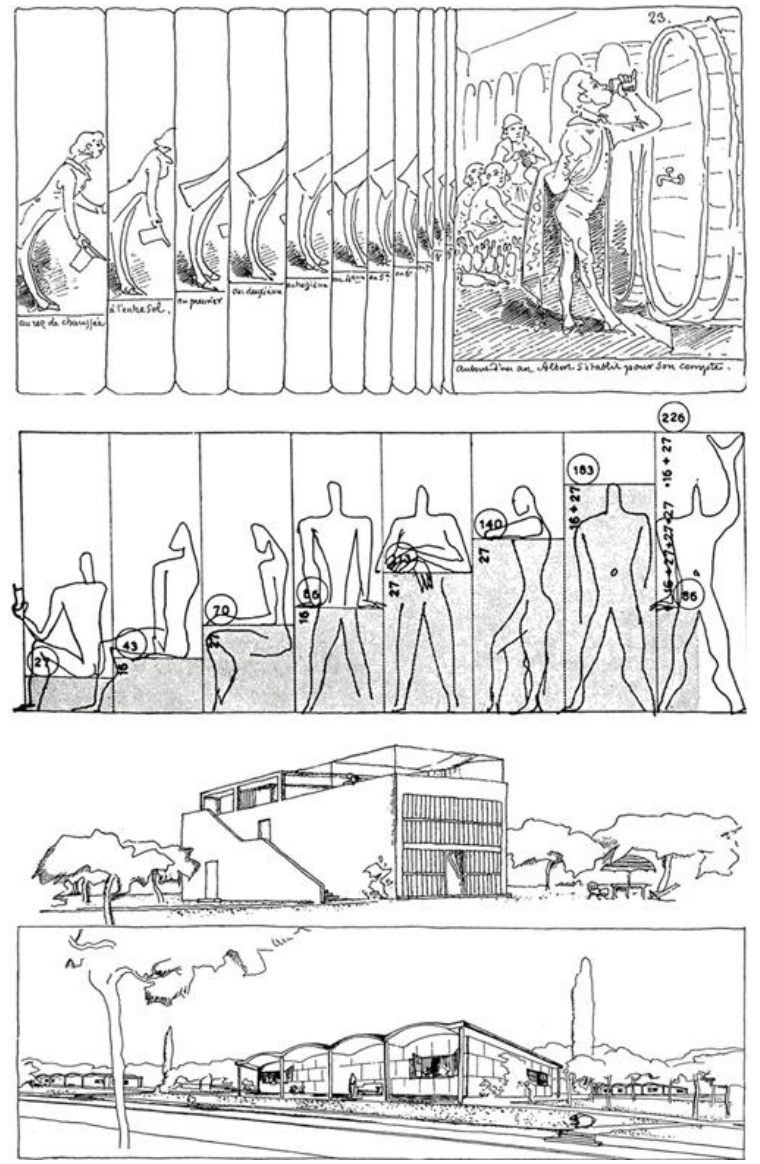

4. L'Esprit Nouveau and drawing: [12], [13] Atelier Primavera des Magasins du Printemps: "Boudoir" (LEN nº 27), and "Cabinet de Travail" ( $\left.L E N \mathrm{n}^{\circ} 28\right)$. [14, 15] Cartoons by Picasso in André Salmon's "Vie Anciene" (LEN no 26).

5. Töpffer / Le Corbusier: Sequential drawing and Platonic utopias: [16] Rodolphe Töpffer: Plate from Histoire d'Albert,, 1845. [17] Le Corbusier: Le Modulor., sequence of proportions in relation to height, 1954. [18-19] Le Corbusier-Saugnier: Renderings of the Maison Citrohan (1921) and the Maison Monol (1919) published in "Maisons en Série" (LEN n 13). CFLC-ADAGP.

But also, Töpffer's works had an additional quality also reflected on Le Corbusier: Töpffer's simplified, pervasively linear style spawned both from the requirements of the printing technique he used, and from their nature as a vehicle for the narrative. And this narrative aspect is a key element when analyzing Le Corbusier's graphic production. As Colomina points out, in relation with Corbusier's use of advertising techniques, he frequently used 'the association of ideas that can be produced through the juxtaposition of images and of images with writing.' In Le Corbusier, '[i]mages are not used to "illustrate" the text; rather they construct the text ${ }^{21}$. Certainly, the juxtaposition of images and words was frequent in Le Corbusier, who found in the different forms graphic narrative a useful communication tool.

\footnotetext{
${ }^{21}$ Publicity brochure for Vers une architecture, 1923 (?). See Colomina, Op. cit., p. 15.
} 


\section{Linear narratives and Narratives en Zigzag.}

"Los dibujos que ilustran diversos proyectos de Le Corbusier hacen uso de un heterodoxo orden narrativo... los textos incluidos (la voz en off del arquitecto) evolucionan a la par de las imágenes, configuran una narración próxima al lenguaje fílmico o al del cómic e introducen el tiempo en el espacio, que sería difícilmente perceptible desde un estático punto de visión. "22

One of the first instances where Le Corbusier used some sort of graphic narrative might be his plate for the article Classement et Choix ${ }^{23}$ ('Ordering and Choice') in L'Esprit Nouveau $\mathrm{n}^{\mathrm{o}} 21$ (1921). Here, after a succinct recount of his intermittent Grand Tour of 1907-11, he concluded with a 'menu' of sorts (the term is used by von $\operatorname{Moos}^{24}$ ) where he presented four 'tasty bits' of his trip: Pera (Istanbul), Istanbul as seen from the Bosporus, a third panel containing isolated domes, arched windows and superimpositions of geometrical shapes, and finally, a drawing of Siena's skyline. All images were framed in four consecutive panels with captions on their right, making the whole work like one of Töpffer's comic strips lying on its side. As von Moos notes, "[t]he focus of interest lies not so much in the urban configurations as such, but in the mechanism of their perception. As with "Mr. Pencil" in Topffer's "strip," it is the drawing that matters, not the landscape it represents... the emotion a place generates, not the nature of that place as such. ${ }^{25 "}$ Indeed, the whole tableau seems to work mainly as a linguistic exercise where Le Corbusier tests the possibilities of the comic strip as a communication device, playing with the alliterations between the urban landscapes he represents in order to articulate a visual narrative in the mind of the reader in a more effective way than an illustrated text would. In that sense, the mechanism works, for the adjacency between the cityscapes, all represented in a similar style, conveys a certain cinematographic illusion: In the eye of the reader -the contemporary reader, at least- the changes of size, scale, and point of view read as a camera zooming in an out on an urban landscape.

This and other examples of panel grids used to frame images, or sequences of images and texts arranged on the page in order to build a discourse, are frequent and varied in Le Corbusier's production, and L'Esprit Nouveau featured several of them: The essay "Sur la Plastique", published in the first issue (LEN no 1, 1920; 38-48) and signed by Le Corbusier and Ozenfant, contains several pages with figures made of different arrangements of square panels housing repeated objects, lines, drawings of buildings, or photographs with varying degrees of similarity with the language of comics: A four-panel strip on top of page 44, which features four vistas of different buildings, conveys a similar narrative feeling as Classement et Choix, albeit without the use of words. The arrangement of squares at the bottom of the same page works mostly as an abstract diagram that explains the geometrical patterns behind drawings, facades and buildings. The drawings on page 43, with its variations on the surface of a cylinder, and on page 45, which encases artworks by Monnet, Rodin, Juan Gris, Seurat, and archaic sculptures, classifying them as 'mauvais' or 'bon', are closer to a true 'menu' of images, and to the sensibility of Magritte's subsequent Les Mots et Les Images (La Révolution Surréaliste $\mathrm{n}^{\circ}$ 12, December 15, 1929), even if devoid of the latter's narrative quality.

\footnotetext{
${ }^{22}$ Baltanás, José: Le Corbusier, promenades. Barcelona: Editorial Gustavo Gili, 2005

${ }^{23}$ Le Corbusier: “Classement et Choix”. In L'Esprit Nouveau nº 21, 1925.

${ }^{24}$ Rüegg. Op. Cit., note 13, p. 26

${ }^{25}$ Ibid, p. 27
} 
A different take on the use of the grid can be found in Le Corbusier's 'iconostatic' layout for Le Poeme de l'Angle Droit, where the different plates were thematically arranged in a series of horizontal strips. Theoretically, this arrangement was supposed to suggest a conventional left-to-right, top-to-bottom reading order; however, the juxtaposition of the strips blurred them into a bigger, encompassing grid that opened the possibilities to establishing other reading orders, or even non-sequential narratives, as some experimental comics do nowadays. The publication in book format constructed a more conventional narrative; however, the graphic proximity of the rendering style and the calligraphy provides an integration between text and image that prevents it from becoming neither an illustrated text nor a commented picture book. Here, too, words and pictures work as a whole.
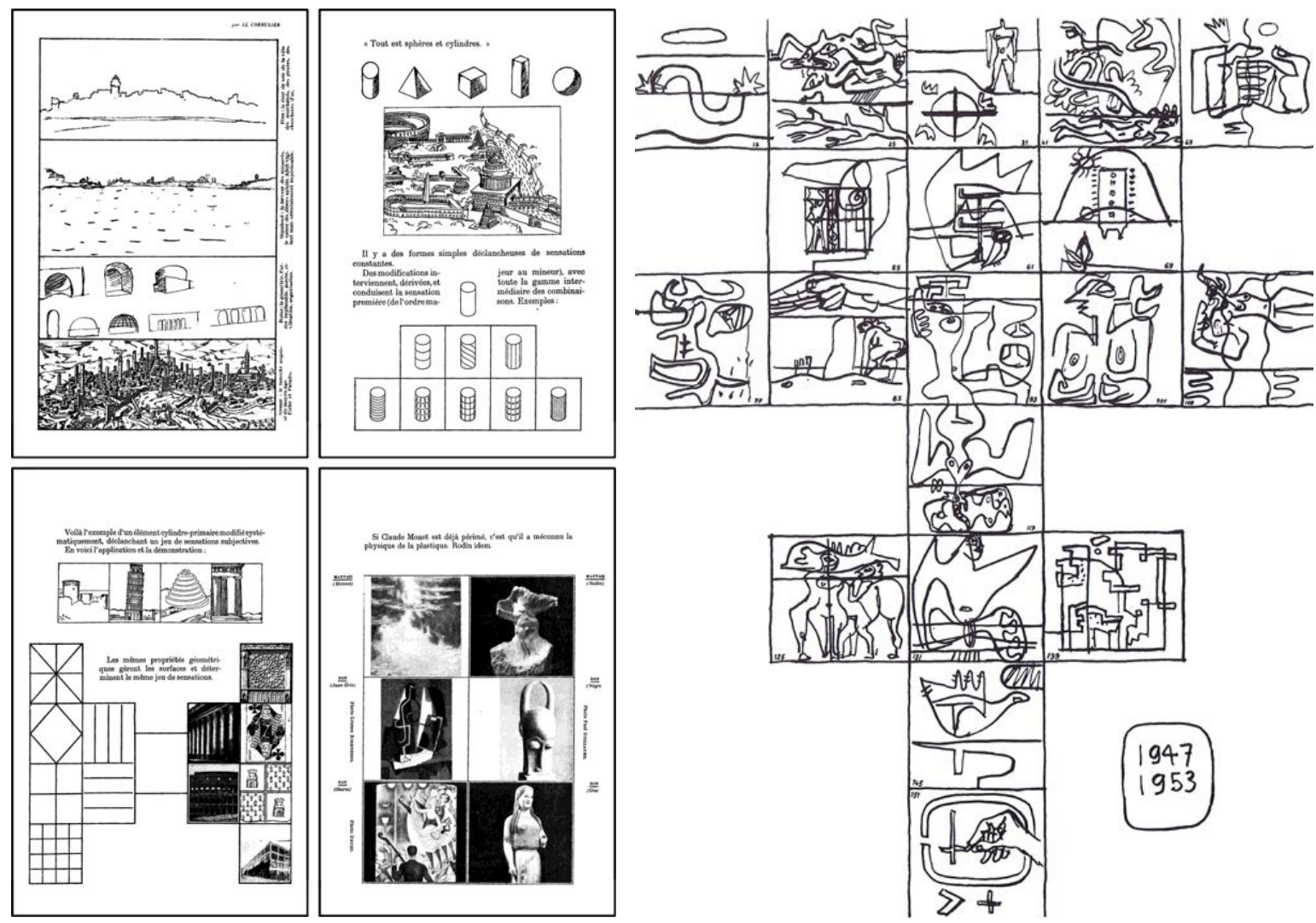

6. Ordering and panels: [20] Le Corbusier: Classement et Choix, $\left(L E N n^{\circ} 21,1924\right)$. [21-23] Le Corbusier and Ozenfant: Sur la Plastique, (LEN n 1, 1920). OFLC-ADAGP.

7. Ordering and panels: [24] Le Poème de l'Angle Droit: Layout of the plates. OFLC-ADAGP.

This is hardly surprising. After all, the year 1918, which marked Le Corbusier's breakthrough into purism, also marked the first publication, among others, of Guillaume Apollinaire's Calligrammes. These hybrid forms indubitably helped define the imaginary of a still young Charles-Edouard Jeanneret, as Apollinaire's presence in $L^{\prime}$ Esprit Nouveau seems to confirm ${ }^{26}$. Adding to the use of panels, the combination of words and pictures, generally organized in a sequence of drawings in cascade, was another favourite of Le Corbusier that can be found at every point of his career: very obviously in cinq points d'une Architecture Nouvelle, most notably in les quatre compositions, and all throughout his multiple explicative -and narrative- sketches drawn in and around his conferences.

\footnotetext{
${ }^{26}$ See "Calligrammes" (LEN n 21 , March 1924; 103-7), and the entire $L E N \mathrm{n}^{\circ} 26$ (October 1924), a special issue dedicated to Apollinaire.
} 


\subsection{A matter of context}

Strange as they may seem from today's perspective, when Le Corbusier's figure is undetachably linked to the realm of high art, these excursions into the popular, the lowcult, the lesser forms of expression, were just a natural response to the zeitgeist of the time, and help illustrate the unprejudiced interest that the new forms of visual narrative arose in the artistic world. If Goethe had enjoyed Tópffer's early proto-comics (or proto-comic strips), the avant-garde certainly did not disregard the power of the newly-born form. Working in a moment where comics, heir to the tradition of the satirical press, were not firmly encoded as a medium for children yet, artists such as Pablo Picasso, George Grosz, or the surrealists ${ }^{27}$, were great admirers of 'the funnies', while others, such as Sergei Eisenstein where passionate admirers of the cartoonists (Honoré Daumier, in Eisenstein's $\operatorname{case}^{28}$ ). Through Gertrude Stein, we know that Picasso was a dedicated reader of Rudolph Dirks's Katzenjammer Kids, a strip made in the image of Max und Moritz, the series created by 'that' Busch mentioned by Le Corbusier ${ }^{29}$. Wilhelm Busch, on the other hand, was a very real influence in George Grosz's work, who admitted that he 'very much liked to flip through Wilhelm Busch' (as did Sigmund Freud, or Albert Einstein), even considering him a precursor to surrealism ${ }^{30}$. Paul Klee, on the other hand, regarded Busch as the 'First Futurist' and found in him "an intellectual kin". George Herriman's Krazy Kat was greatly admired both by 'popular entertainers such as Disney and Frank Capra', and by the intellectuality of the time, which included writers such as H. L. Mencken, Ernest Hemingway, T.S. Eliot, E.E. Cummings and Umberto Eco, or painters such as, again, Picasso, Joan Miró and Willem de Kooning ${ }^{31}$.

The aesthetics and, less surprisingly, the conventions and mechanics of sequential narrative presented an obvious appeal to an avant-garde scene whose work dealt with the search for a new vision, often related to the introduction of time lapse within perception. This fondness of comics' language was particularly patent among the surrealists: In the 1940s, the catalogue for the New York exhibition First Papers of Surrealism (1942), coorganised by André Breton and Marcel Duchamp included a panel from Superman next to a portrait of Friedrich Nietzsche; and Breton, who decades later would declare himself an admirer of Jean-Claude Forest's Barbarella $^{32}$, used speech balloons in his 1943 illustration Tragic, in the Manner of Comics. Much earlier, roughly at the same time that Le Corbusier was writing about Töpffer, the first issue of the New York Dada Magazine (1921) included a panel by mythical cartoonist Rube Goldberg, whose clumsy, ridiculously complex machineries have been noted by many authors as a precedent for the very similar machines that Duchamp (The Large Glass, 1915-23; Coffee Mill, 1911), and Francis Picabia (Ici, c'est ici Stieglitz, foi et amour, 1915) were producing at that point. This affinity was only natural, since many painters of this generation started as

\footnotetext{
${ }^{27}$ Sculptor David Hare, editor of the surrealist magazine VVV (New York, 1942-44) championed comics in his essay "Comics", published in Les Temps Modernes $\mathrm{n}^{\circ}$ 1, 1946. Hare claimed for the legitimacy not only of comic strips, but even of the 'vulgar' comic books of the 1940s. See Hadler, Mona: "David Hare, Surrealism, and the Comics." In The Space Between: Literature and Culture, 1914-1945. December 2011, Vol. VII, № 1. pp. 93-108.

${ }^{28}$ See Ackerman, Ada: Regards de Sergueï Eisenstein sur l'oeuvre d'Honoré Daumier: une réception méconnue. Advisor(s): Porterfield, Todd; Le Men, Ségolène. PhD Dissertation. Paris: Université Paris-Ouest-Nanterre-La Défense Montréal: Université de Montréal, 2010

${ }^{29}$ See Stein, Gertrude: The Autobiography of Alice B. Toklas. New York: Harcourt, Brace and Company, 1933, pp. 13-15.

${ }^{30}$ A thorough overview of Wilhelm Busch's influence on culture and art during his time and after can be found in Angelika Morris's excellent Manifestations of Wilhelm Busch's Aestheticsin Eduards Traum. Supervisory Committee: Dr. Angelika Arend, Dr. Helga Thorson, Dr. Lisa Surridge. Masters Dissertation. University of Victoria, Victoria (BC), 2010.

${ }^{31}$ See Heer, Jeet: "Krazy Kat reprinted by Fantagraphics". In National Post. Toronto: Postmedia Network, April 2002, and O'Connell, Karen et al: Krazy Kat: The Comic Art of George Herriman. New York: Harry N. Abrams, 1986.

${ }^{32}$ See Forest, Jean Claude: "Ma vie, mon oeuvre, en douze pages, pour en finir avec cet episode et passer a autre chose". In $A$ Suivre. January 1984, № 73. pp. 45-56.
} 
commercial humorists; Duchamp himself wanted to launch a career as a humorous cartoonist before turning to the higher plateau of Fine Arts ${ }^{33}$.

Many avant-garde artists experimented with comics at one point or another: both Dalí and Eisenstein -who was a consummated caricaturist-, drew comic strips in their youth ${ }^{34}$, and even Picasso produced a series of 5 consecutive drawings with captions made on occasion of a trip to Barcelona in 1904. But most interestingly, many of those incorporated sequential narratives in their work too: René Magritte used multi-panel compositions in several occasions, such as The Interpretation of Dreams (1935) -a variation on Les Mots et les Images-, l'arc en ciel (1948), and l'homme au journal (1928), a four-panel composition where the disappearance of the main character after the first frame suggests the lapse of time. Speech balloons were also frequent in his works, such as l'usage de la parole (1928) or Drat! (1948). Dalí, on the other hand, created several works that showed a clear affinity with comics while he was living in New York: "Crazy Movie Scenario", one of the illustrations he produced for The American Weekly, and two beautiful pages of preparatory designs for the ill-fated film Les Mystères surréalistes de New York (1935) that stood somewhere in between a storyboard and a comic strip ${ }^{35}$. Even Picasso, whose work has often been qualified as narrative -even if sometimes in a derisive way ${ }^{36}$ - used the narrative possibilities of the panel sequence in Songe et Mensonge de Franco (1937), two plates of "etchings in comic-strip form" where he depicted Franco's "calamitous effect on civilization and on the lives of ordinary citizens $^{\prime \prime 37}$.
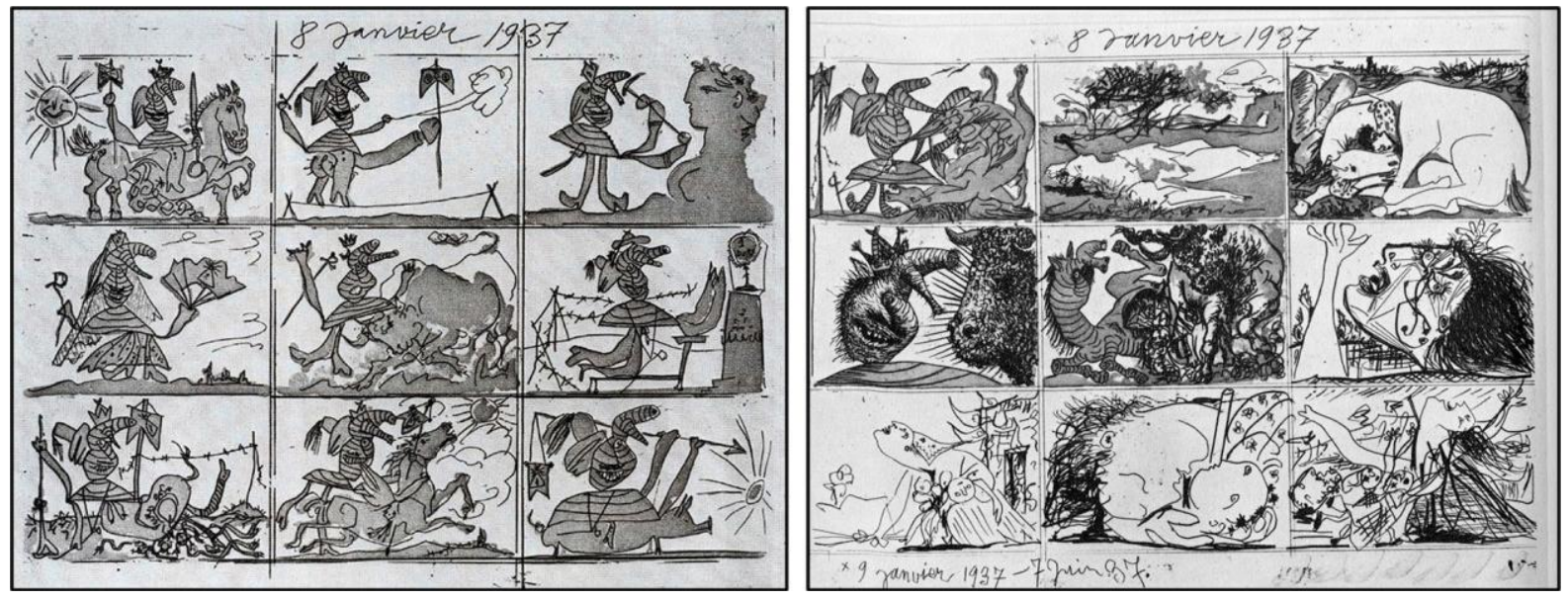

8. Surrealism and bande dessinée. [25] Pablo Picasso: Songe et Mensonge de Franco (1937).

\footnotetext{
${ }^{33}$ For a survey on the connections between the Surrealists and Rube Goldberg, see North, Michael: "Goldberg Variations". In Machine-Age Comedy. New York: Oxford University Press, 2008.

${ }^{34}$ In 1916, a 12-years-old Salvador Dalí drew a series of one-page strips -possibly copied from magazines- as well as singlepanel cartoons for his younger sister Ana María [see Raeburn, Michael (dir.): Salvador Dalí: the early years. London: Thames \& Hudson, 1994].

${ }^{35}$ A survey on Dalí's excursions into comics and cartooning can be found in Roig, Sebastià: "Els ninots de Dalí". In Diari de Girona, Sunday Supplement, August 72011.

${ }^{36}$ I am referring to Georges Boudaille's review of the Salon de Mai in 1968. See Holloway, Memory Jockisch: Making Time: Picasso's Suite 347. New York: Peter Lang Publishing, 2006, p. 33.

${ }^{37}$ Utley, Gertje: Picasso: The Communist Years. New Haven: Yale University Press, c2000, p. 18. One of the earliest and most vocal proponents of the relationship between Songe et Mensonge de Franco and comics was Gerald Gassiot-Talabot, who made this connection for the first time in the exhibition La Figuration narrative Dans l'art contemporain' (Galerie Europe / Galerie Creuze, October 1965). See also: Couperie, Pierre; Gassiot-Talabot, Gerald: Bande Dessinée et Figuration Narrative, Paris: Musée des Art Decoratifs, 1967. Some authors even argue that Roy Lichtenstein's variations on Picasso's Woman in an Armchair are a comment on the Spanish painter's fondness of comics.
} 
The avant-garde's relationship with comic books was old and deep, and can be tracked back almost to the origins of the medium, as pointed out by Lyonel Feininger, whose etching Kathedrale (1919) was used by Walter Gropius in the Programm des Staatlichen Bauhauses in Weimar to illustrate the 'synthesis of the arts'. Long before breaking out as a renowned painter and member of the Berliner Sezession and the German expressionist groups (Die Brüke, Der Blaue Reiter, the Novembergruppe et al), Lyonel Feininger had been a successful cartoonist and one of the pioneers of American comics, creating two comic strips, "The Kin-der-Kids" and "Wee Willie Winkie's World" 1906-7 for the Chicago Tribune that stand as landmarks in the history of the medium.

Le Corbusier was certainly aware of all the agitation that was taking place in an avant-garde scene he himself belonged to, glimpsing the potentialities of this transmediatic hybridization between mass media and art, between fine arts and popular culture. One can only imagine Le Corbusier's joy when he was given back Louis Soutter's 'illustrated' version of Une Maison, un Palais (1928), with its pages turned into beautiful pictograms. However, Le Corbusier's interest in graphic narrative seems to spawn less from its abilities for artistic agitation than from a search for clarity. Töpffer's strips were so valuable because of their inherent economy: they were ideal because they were the perfect vehicle to transmit a clear, distinct message; because their simple, abstract outlines could be completed in the reader's mind with all the details they lacked, not letting the latter obstruct the flux if the narrative. All these aspects are very vividly illustrated by Le Corbusier's presentation of his Ville Contemporaine (1922) in the last issue of L'Esprit Nouveau (January 1925), where the overlap with Töpffer makes itself more evident, depicting the project was depicted in a cinematographic sequence of four panoramic panels with captions that fit in the tradition of the XIX Century 'broadsheets' where Busch's drawn stories had been gestated.
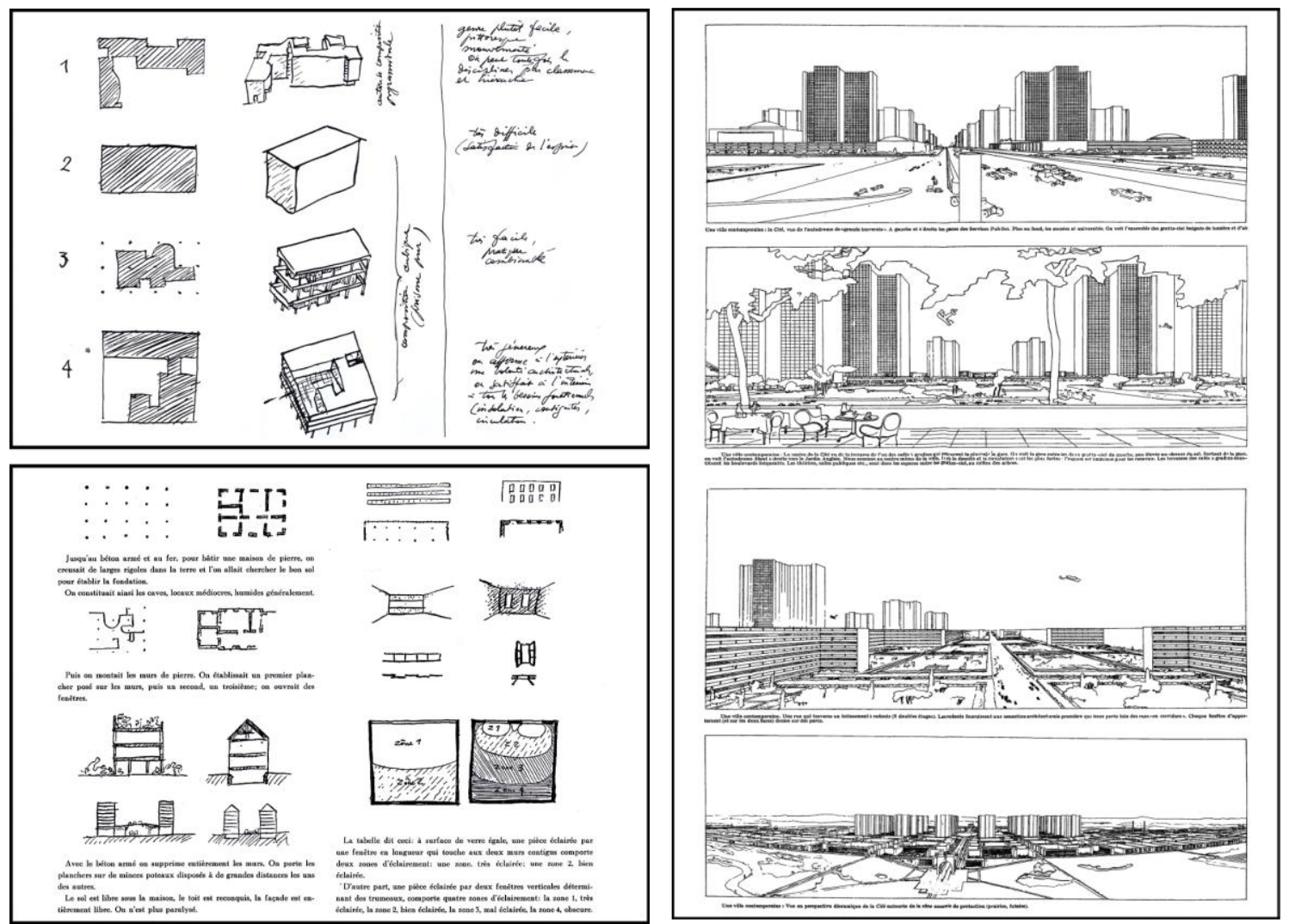

9. On Storytelling. [26] Les quatre compositions, 1929. [27] Cinq points d'une architecture nouvelle, c1927. OFLC-ADAGP.

10. [28] Presentation of Une Ville Contemporaine (1922) in L'Esprit Nouveau nº 28, January 1925. OFLC-ADAGP. 


\section{Beyond the panel: The Letter to Madame Meyer. From Sequence to multi-sequentiality, from Promenade to Enjambment}

This kind of sequential panoramas, which literalize the cinematographic suggestions of "Claissement et choix" are frequent throughout Le Corbusier's published works. His Oeuvre Complète shows many instances of this, such as the series of drawings of New York from the ferry accompanying "Méditation sur Ford" (OC 1934-38, pp. 16-7), the vignettes on the environment of Fort-l'Empereur, or his trip through a simplified Paris in La Ville Radieuse. Digging through his working documents, we can also find many occasions where he used narrative, sequences of drawings, vignettes, or storyboard-like compositions for multiple purposes. In the aforementioned "Le Corbusier and Photography", Beatriz Colomina shows some of those: a series of vignettes with instructions to modify some photographs of S. Maria di Cosmedin for their publication in Vers une architecture; a page of sketches from the draft manuscript of Vers une... which could easily be mistaken for a preliminary for Magritte's Les Mots et les Images; or a drawing by Le Corbusier with the word "Roneo" on top illustrating sequentially his controversy with Auguste Perret over the fenêtre en longueur.

However, from an architectural point of view, the most interesting documents are those where graphic narrative appears as a tool used to represent a specific conception of architectural space. In Le Corbusier's career, this moment is unquestionably represented by his Lettre a Madame Meyer (1925), wherein the Swiss architect introduced the client to his design concepts for the never-built Ville Meyer at Neuilly-sur-Seine through a series of footnoted sequential vistas of the house. Anecdotic as it might seem, this letter -actually an annotated storyboard- marks a key moment in the evolution of Le Corbusier's conceptualization of space, both by recording it (the change), and by providing the architect with a tool to represent and explore his new conception. As Bruno Reichlin explains in his seminal "Jeanneret - Le Corbusier, Painter/ Architect" ${ }^{38}$, in the lapse from the 1900 s to the 1930s, Le Corbusier's conceptualization of space evolved from the fragmented compartmentation of Beaux Arts architecture, to the sequentiality of the prómenade architecturale and, finally, to the simultaneity of architectural enjambment. In his discussion, Reichlin argues that this evolution from a sequential to a simultaneous conception of space, where architectural spaces interpenetrate each other, is related to Jeanneret's experiments in purism: Therefore, paintings such as The Red Bowl (1919) or Still Life with Stack of Plates and a Book (1920) display a space that unfolds under the glance of the spectator, revealing, behind their apparent flatness, the coexistence of different spaces that overlap in silent collision.

\footnotetext{
${ }^{38}$ Reichlin, Bruno: "Jeanneret/Le Corbusier, Painter-Architect". In Blau, Eve; Troy, Nancy J. (eds.): Architecture and Cubism. Montreal: Canadian Centre for Architecture; Cambridge, Mass: MIT Press, 1997. pp. 195-218.
} 

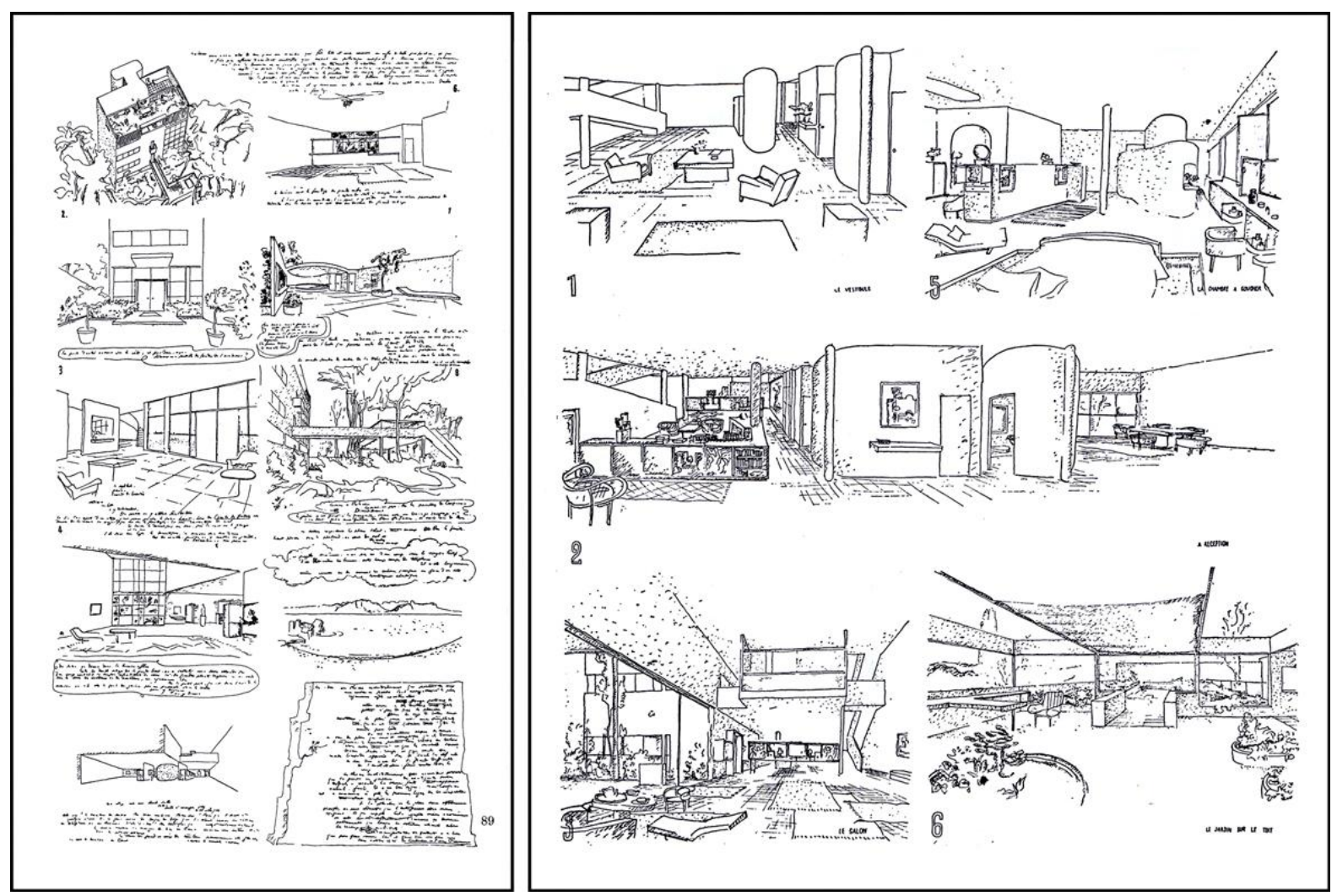

11. The Letter to Madame Meyer. Le Corbusier: Lettre a Madame Meyer, October 1925. Original document [29] and an excerpt of a sheet with sketches for the second project [30]. OFLC-ADAGP.

In this context, Reichlin argues that the letter, in which the architect exploited 'all the cinematic possibilities of the cartoon', rendered a space where "... perspectives extended to the point of taking in an entire itinerary. They presuppose movable points of view, cavalier perspectives, and rapid zoom shots, from panoramic view to closeup of plan. Explanatory cartoonlike 'bubbles' are inserted to avoid breaking the optical continuity that the drawings suggest, and to prevent the reader from mistaking these drawings -these graphic annotations- for illusionistic renderings of the building to be built." Certainly, they were not supposed to be built, because they were, rather than the representation of an architectural space, the representation of the perception of that space. Previously we noted how cinema, a discipline located in the intersection between technology and art and capable of gathering together image and narration, was inevitably chosen as the medium to capture and reproduce the fast experience of space that the new urban world brought about. However, the reality of the modern perception of space entailed a multiplication of the points of view which, alchemically fused in the flâneur's retina throughout time, generated a simultaneous experience of space: both the one in front of the viewer, but also those spaces perceived with the corner of the eye, and even those he just walked through, retained by retinal persistence. This is the type of perception that the avant-garde, be it via collage or cubist painting, tried to represent, introducing kaleidoscopic visions bred in the post-humanist refusal of a privileged point of view.

These are also the two modes of vision that can be identified in Le Corbusier, exemplified by his cinematic perception of the Acropolis in Athens (Vers une Architecture, 1923), and the simultaneous perception of space depicted by the Lettre a Madame Meyer. It is in this context where the letter, a marginal document that stands somehow out -tangent at most- of the general line of Reichlin's discourse, bears, however, a pivotal role in the full understanding of the influence of purism on Le Corbusier's move towards enjambment, and shows that his disparate interests in the different media are in fact parts of a single exploration. To a certain extent, it works as a 
mediator between cinema and purism, and between the latter and architecture. On the one hand, with its introduction of a space-time sequence within the encompassing space of the page, the graphic narrative of the letter mediates between the substitutive sequentiality of cinema, where each moment is automatically replaced by the next one, and the simultaneity that we find in purist painting. As opposed to the temporal sequence, the letter builds a physical sequence in praesentia ${ }^{39}$ where each individual space can be inspected in isolation, while still perceiving its connection with the rest. Thus, the concomitances between La Lettre and purism unveil a further presence in the latter's spatial juxtaposition/superimposition: Along with the multispatiality pointed out by Reichlin, we can argue that purist paintings enclosed -in a less rhetorical way than cubist painting ${ }^{40}$ - a multitemporal experience, becoming, like the cartoon, a still mechanism that gets activated under the effect/action of the glance of the reader. In this context, La lettre becomes especially significant because it clarifies this journey from painting to architecture by showing the encounter of Jeanneret and Le Corbusier in a medium that offered a meeting point between painting and architectural design, and between the abstraction of purism and the concretion of architectural rendering.

The spatiotemporal qualities of la Lettre a Madame Meyer become even clearer when comparing it with the pages of the comics available at the time, which had already evolved from single strips to full-tabloid pages. In this sense, the most vivid example might be the well-known plates of September 22 and 29, 1907, of Little Nemo in Slumberland, where Winsor McCay took his characters on a dreamlike journey through a hyperbolic Manhattan. Free from the constraints of reality, McCay built a much more complex version of the letter's multispace, but the mechanics are essentially the same. In this case, the espace encadré (framed space) of each single panel is merged, with the mediation of the immaterial ether that fills the space between frames, into a supraspace conformed by the joint perception of the espace multicadre (multi-panel space) of the page. In McCay's case, this supraspace appeared in the form of a non-Euclidean, hyperurban scenario that underlined the urban origin of the kaleidoscopic/panoptic vision cultivated by the Cubists. However, it is notable how Reichlin's remarks ('the cinematic possibilities of the cartoon', 'perspectives extended to the point of taking in an entire itinerary', 'movable points of view', 'optical continuity') could equally be used to describe these plates. Curiously enough, the same kaleidoscopic vision can also be found in a sketch drawn by Le Corbusier that same year: an annotated study of Santa Croce in Florence, done during his first trip to Italy, where the viewing eye became progressively fragmented and the watercolours gave way to a more synthetic, linear style.

\footnotetext{
${ }^{39}$ For some insight on the concept of sequence in praesentia, see Groensteen, Thierry: "Töpffer: the Originator of the Modern Comic Strip". In Lefèvre, Pascal; Dierick, Charles (eds.): Forging a New Medium: The Comic Strip in the Nineteenth Century. Brussels: VUB University Press, 1998, p. 108.

${ }^{40}$ As Reichlin notes, "[i]n theoretical writing on cubism, the theme of duration, the time required to read a work, to read a representation that in fact has the notion of time implicit in it, constantly recurs... But the theme of duration was in the air at the time." To support this comment, Reichlin quotes Jean Metzinger in "Cubisme et la tradition" (Paris-Journal, August 16, 1911): "([he cubists] have allowed themselves to move around the object... Formerly a picture took possession of space, now it reigns also in time." See Reichlin, op. cit., note 28, p. 216.
} 

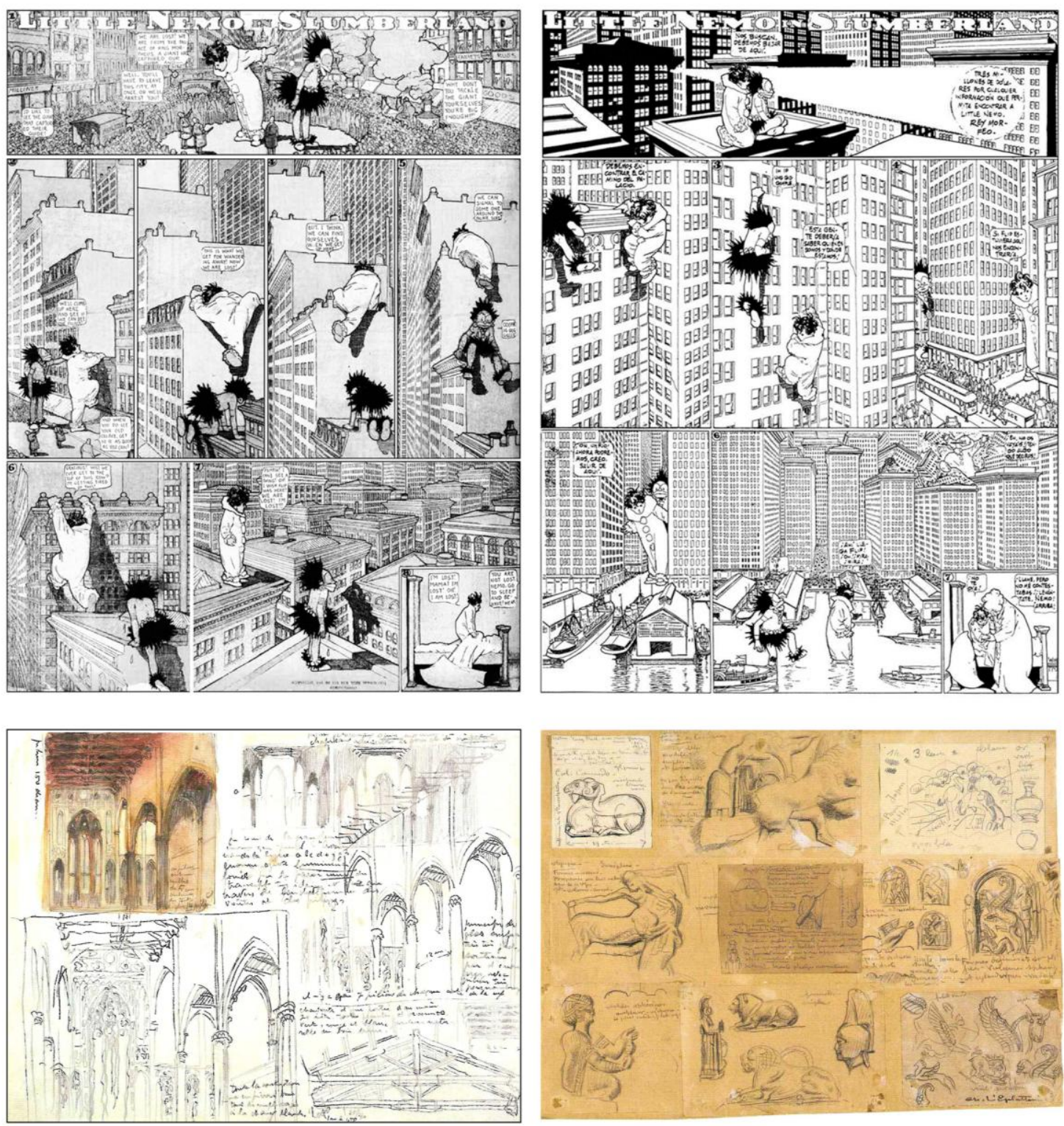

12. 13. Kaleidoscopia. [31, 32] Winsor McCay: Little Nemo in Slumberland, Sunday pages from September 22 and $29,1907$. [33] Charles-Edouard jeanneret, Interior Study of S. Croce, Florence, 1907. pencil and watercolor on ivory paper, FLC (149). CFLC-ADAGP [34] Charles L:Eplattenier, Monumental sculptures from various museums (including the Louvre?), pencil and ink on 9 sheets of notepaper, pasted on wrapping paper.

Thus presented, the evolution of Le Corbusier's conception of architectural space (compartmentation / promenade / enjambment) mirrored the development of the mechanics of graphic narrative (broadsheet /comic strip / comic page): The broadsheets, an ancestor of comics that had gained an increasing popularity by the eighteenth century had consisted generally of a static succession of commented scenes usually arranged within a grid. Töpffer's revolution in the 1830s was to imbue the medium with a cinematic impulse, by making them actual bandes dessinées (literally drawn strips) that captured movement and depicted spatially the lapse of time. Thus, Töpffer precluded, more than half a century before the advent of cinema, the form of the filmstrip and the very logic of the unidirectional montage of cinematography. By the 1910s, this cinematic impulse had already been expanded from the unidirectionality of the strip into the two-directional space of the page. 


\section{Beyond Purism (A Conclusion).}

Beyond their interest as isolated elements of study, all these concomitances, only help underline the role that apparently minor disciplines may have in the understanding of the architectural fact. This is even more necessary when studying Le Corbusier, whose omnivorous appetite for anything related to visual culture, paired with his transversal, promiscuous understanding of architecture, makes the examination of the periphery of the discipline -of culture, even- almost obligatory. In this sense, the exploration of Le Corbusier's relationship with Töpffer, with cartoons, and, in an ampler spectrum, with the medium of comics -whose development overlapped with Jeanneret's own life-, helps complete the understanding of his relationship with the media, but even more interestingly sheds some new light on crucial aspects of his figure: his search of a certain approach to drawing, his aesthetic preferences, his use of communicational tools, and even the evolution of his conception of space. From its location within popular culture, the presence of the bande dessinée suggests a new direction that helps build the grounds where Le Corbusier's aesthetic imaginary was forged, opening up new aspects of his complex personality, and bringing in a new angle about the multi-faceted context in which modern architecture was gestated.

\section{Source of images}

[1-4] Le Corbusier (De Fayet): “Toepffer, précurseur du cinema". Printed in L'Esprit Nouveau No 11-12, November 1921, pp. 1336-1346. [5] Le Corbusier: La ville radieuse, éléments d'une doctrine d'urbanisme pour l'équipement de la civilisation machiniste. Boulogne (Seine): Éditions de l'architecture d'aujourd'hui, 1935, p. 208. [6-9] Le Corbusier: L'Art decoratif d'aujourd'hui, 1925. Printed in Colomina, (1987), p.9. [10] Rodolphe Töpffer: sketches. Source unknown. [11] Rodolphe Töpffer: Essai de physiognomonie. Genève: par autographié chez Schmidt, 1845, p. 25. [12] Printed in L'Esprit Nouveau no 27, November 1924. [13] Printed in L'Esprit Nouveau n ${ }^{\circ}$ 25, July 1924. [14, 15] Pablo Picasso: Cartoon for André Salmon's article "Vie Anciene". Printed in L'Esprit Nouveau no 26, 1924. [16] Rodolphe Töpffer: Histoire d'Albert, Geneva: Self-published, 1845, p. 23. [17] Le Corbusier: Le Modulor, sequence of proportions in relation to height, and to harmonic furniture dimensions, c1946. FLC 7125. [18, 19] Le Corbusier-Saugnier: Maison Citrohan (1921); Maison Monol (1919) in "Maisons en Série". L'Esprit Nouveau $\mathrm{n}^{\circ}$ 13, December 1921. [20] Le Corbusier: Illustration for "Classement et Choix", L'Esprit Nouveau no 21, March 1924, pp. 1539, 1540-1. [21-23] Le Corbusier and Ozenfant: Illustrations for "Sur la Plastique", L'Esprit Nouveau n ${ }^{\circ}$ 1, October 1920, pp. 43-5. [24] Le Corbusier: Le Poème de l'Angle Droit: Lithographies Originales. Paris: Tériade, 1955. [25] Pablo Picasso: Songe et Mensonge de Franco (1937). National Gallery of Canada, $\mathrm{n}^{\circ} 18726.1$ and 18726.2. [26] Le Corbusier: Les quatre compositions, 1929. Printed in Oeuvre complète1910-1929. Zurich: Erlenbach, Éditions d'architecture, 1946, p. 189. [27] Le Corbusier: Cinq points d'une architecture nouvelle, ibid, p. 129. [28] Le Corbusier: Une Ville Contemporaine (1922). Printed in L'Esprit Nouveau no 28, January 1925. [29] Le Corbusier: Lettre a Madame Meyer, October 1925. Printed in Oeuvre complète1910-1929. Zurich: Erlenbach, Éditions d'architecture, 1946, p. 88. [30] Le Corbusier: Villa Meyer, Neuilly-sur-Seine. Second Project, c1925. Ibid, p 90. [25] Idem. Property of FLC. [27], [28] Winsor McCay: Little Nemo in Slumberland. New York Herald, 1907. [29] Charles-Edouard Jeanneret, Interior Study of S. Croce, Florence, 1907. FLC (149). Printed in Von Moos (2002), p. 30. [30] Charles L'Eplattenier: sketches. Bibliothèque de la Ville de La Chauxde-Fonds - Fonds Le Corbusier (277). Printed in Von Moos (2002), p. 160.

\section{Bibliographical References}

Ackerman, Ada: Regards de Sergueï Eisenstein sur l'oeuvre d'Honoré Daumier: une réception méconnue. Advisor(s): Porterfield, Todd; Le Men, Ségolène. PhD Dissertation. Paris: Université Paris-Ouest-Nanterre-La Défense - Montréal: Université de Montréal, 2010.

Aylmer, Maude: The Life of Tolstoy: First Fifty Years. New York: Dodd, Mead, 1910.

Baltanás, José: Le Corbusier, promenades. Barcelona: Editorial Gustavo Gili, 2005. 
Colomina, Beatriz: "Le Corbusier and Photography". In Assemblage. October 1987, № 4. pp. 6-23.

Corbusier, Le; Ozenfant, Amédée: L'Esprit Nouveau. 28 issues, Paris, 1920-5.

Corbusier, Le: Almanach d'architecture moderne. Paris: Éditions Crès, "Collection de l'Esprit Nouveau", 1925.

Corbusier, Le: Une maison - un palais. "A la recherche d'une unité architecturale.". Paris: Éditions Crès, "Collection de l'Esprit Nouveau", 1928.

Corbusier, Le: Creation is a patient search. New York: Frederick Praeger, 1960. English translation of L'Atelier de la recherche patiente, Paris: Vincent \& Fréal, 1960.

Couperie, Pierre; Gassiot-Talabot, Gerald: Bande Dessinée et Figuration Narrative, Paris: Musée des Art Decoratifs, 1967.

Edera, Bruno: Histoire du cinéma suisse d'animation. Lausanne: Cinémathèque suisse, 1978.

Forest, Jean Claude: "Ma vie, mon oeuvre, en douze pages, pour en finir avec cet episode et passer a autre chose". In A Suivre. January 1984, № 73. pp. 45-56.

Groensteen, Thierry; Peeters, Benoît: Töpffer: L’invention de la Bande Dessinée. Paris: Hermann, 1994.

Groensteen, Thierry: "Töpffer: the Originator of the Modern Comic Strip". In Lefèvre, Pascal; Dierick, Charles (eds.): Forging a New Medium: The Comic Strip in the Nineteenth Century. Brussels: VUB University Press, 1998. pp. 105-14.

Hadler, Mona: "David Hare, Surrealism, and the Comics." In The Space Between: Literature and Culture, 1914 1945. December 2011, Vol. VII, No 1. pp. 93-108.

Heer, Jeet: “Krazy Kat reprinted by Fantagraphics”. In National Post. Toronto: Postmedia Network, April 2002.

Holloway, Memory Jockisch: Making Time: Picasso's Suite 347. New York: Peter Lang Publishing, 2006.

Kunzle, David: Father of the comic strip: Rodolphe Töpffer. Great Comics Artists Series. Jackson: University Press of Mississippi, 2007.

Metzinger, Jean: “Cubisme et la tradition”. In Paris-Journal, August 16, 1911.

Migayrou, Frédéric; Cinqualbre, Olivier: Le Corbusier: Mesures de l'homme. Catalogue of the Exhibition. Paris: Editions du Centre Pompidou, 2015.

Morris, Angelika: Manifestations of Wilhelm Busch's Aesthetics in Eduards Traum. Supervisory Committee: Dr. Angelika Arend, Dr. Helga Thorson, Dr. Lisa Surridge. Masters Dissertation. University of Victoria, Victoria (BC), 2010

North, Michael: "Goldberg Variations". In Machine-Age Comedy. New York: Oxford University Press, 2008.

O'Connell, Karen et al: Krazy Kat: The Comic Art of George Herriman. New York: Harry N. Abrams, 1986.

Raeburn, Michael (dir.): Salvador Dalí: the early years. London: Thames \& Hudson, 1994.

Reichlin, Bruno: "Jeanneret/Le Corbusier, Painter-Architect". In Blau, Eve; Troy, Nancy J. (eds.): Architecture and Cubism. Montreal: Canadian Centre for Architecture; Cambridge, Mass: MIT Press, 1997 pp. 195-218.

Roig, Sebastià: "Els ninots de Dalí". In Diari de Girona, Sunday Supplement, August 72011.

Simmel, Georg: "The Metropolis and Mental Life". Adapted by D. Weinstein from Kurt Wolff (Trans.): The Sociology of Georg Simmel. New York: Free Press, 1950

Stein, Gertrude: The Autobiography of Alice B. Toklas. New York: Harcourt, Brace and Company, 1933

Utley, Gertje: Picasso: The Communist Years. New Haven: Yale University Press, c2000

Vogt, Adolf Max: "Remarks on the 'Reversed' Grand Tour of Le Corbusier and Auguste Klipstein". In Assemblage. October 1987, № 4. pp. 38-51. 
Von Goethe, Johan Wolfgang: Conversations of Goethe with Eckermann and Soret. London: George Bell \& Sons, 1874.

Von Moos, Stanislaus: Le Corbusier, Elemente einer Synthese. Frauenfeld, Stuttgart: Huber, 1968. English translation: Le Corbusier: Elements of a synthesis. Cambridge, Mass.: MIT Press, c1979.

Von Moos, Stanislaus: "Voyages en Zigzag". In Rüegg, Arthur; Von Moos, Stanislaus (eds.): Le Corbusier before Le Corbusier: Applied Arts, Architecture, Painting, Photography, 1907-1922. New Haven: Yale University Press, c2002. pp. 22-43.

Wogensky, André: Le Corbusier Sketchbooks. Cambridge: MIT Press and New York: Architectural History Foundation, 1981- 82. 